\title{
Special Collections, Archives, and Rare Books
}

compiled by Anna Appleman

Cho, James H. and Elayne Gardstein. 2020. "All in the Family: Cataloging the Alice Hoffman Collection.” Technical Services Quarterly 37, no. 4 (October): 376-90. doi.org/10.1080/07317131 .2020 .1810440 .

Davis, Kalan Knudson. 2020. "Leveraging the RBMS/BSC Latin Place Names File with Python.” Code4Lib Journal, no. 48 (May 11). journal.code4lib.org/articles/15143.

Frost, Guy. 2020. "From Zines of Peer Reviewed Journals: Cataloging Contemporary Pagan Resources.” The Serials Librarian 79, no. 3-4 (November): 267-80. dx.doi.org/10.1080/036152 $\underline{6 X .2020 .1851338 .}$.

Haberstock, Lauren. 2020. "Participatory Description: Decolonizing Descriptive Methodologies in Archives.” Archival Science 20, no. 2 (June): 125-38. doi.org/10.1007/s10502-019-09328-6.

Pendse, Liladhar R. 2020. "Building Virtual Collection and Spanish Colonial Imprints of the Philippines.” Collection \& Curation 39, no. 3 (July): 77-88. doi.org/10.1108/CC-07-2019-0020.

Seppi, Gregory and Dainan Skeem. 2020. "Picking Up the Pieces: Library Processes and the Theft of Rare Materials.” RBM: A Journal of Rare Books, Manuscripts, \& Cultural Heritage 21, no. 2 (Fall): 98-118. doi.org/10.5860/rbm.21.2.98.

Stead, Oliver and Chern Li Liew. 2020. "Editorial Cartoon Collections: A Review of Indexing Challenges.” Aslib Journal of Information Management 72, no. 3: 421-38. dx.doi.org/10.1108/ AJIM-10-2019-0288. 